\title{
Characterizing Engineering Outreach Ambassadors' Teaching Moves during Engineering Design Activities (Fundamental)
}

\author{
Ms. Elizabeth Ann Moison, Tufts University \\ Center for Engineering Education and Outreach
}

\section{Ms. Karen Miel, Tufts University}

Karen Miel is a PhD student in STEM Education at Tufts University. Karen served as the Director of Research and Innovation at the science center CuriOdyssey and the Education Director of the Palo Alto Junior Museum and Zoo after teaching elementary and middle school. Her research focuses on elementary students' reasoning and decision-making in collaborative engineering design.

\section{Dr. Merredith D. Portsmore, Tufts University}

Dr. Merredith Portsmore is the Director for Tufts Center for Engineering Education and Outreach (www.ceeo.tufts.edu). Merredith received all four of her degrees from Tufts (B.A. English, B.S. Mechanical Engineering, M.A. Education, $\mathrm{PhD}$ in Engineering Education). Her research interests focus on how children engage in designing and constructing solutions to engineering design problems and evaluating students' design artifacts. Her outreach work focuses on creating resources for K-12 educators to support engineering education in the classroom. She is also the founder of STOMP (stompnetwork.org), LEGOengineering.com (legoengineering.com) and the Teacher Engineering Education Program (teep.tufts.edu).

\section{Dr. Kelli Paul, Indiana University-Bloomington}

Dr. Kelli Paul is a postdoctoral researcher in science education at Indiana University. She received her Ph.D. in Educational Psychology specializing in Inquiry Methodology from Indiana University in 2006. She managed a consulting business for 10 years working on evaluations that focused primarily in the areas of education and STEM for middle and high school students, especially women and minority students. Her research interests include student engagement and interest in STEM and STEM careers as well as the development of instruments and evaluation tools to assess these constructs.

\section{Dr. Adam Maltese, Indiana University-Bloomington}

Associate Professor of Science Education

\section{Dr. Jungsun Kim}




\title{
Characterizing Engineering Outreach Ambassadors' Teaching Moves during Engineering Design Activities (Fundamental)
}

\begin{abstract}
Engineering outreach programs have the potential to significantly influence precollege youth; university-led engineering programs reach approximately 600,000 K-12 students each year in the United States. Despite the prevalence of these outreach programs, little is known about the nature of the discursive interactions between outreach ambassadors and participating youths and the ways in which these interactions support youths' progress in engineering. Understanding the ways in which outreach ambassadors support youth to learn engineering is critical to furthering the effectiveness of these programs and contributes to greater understanding about how to support engineering in K-12 settings. Often, these programs are facilitated by undergraduate and graduate engineering ambassadors who themselves are developing as engineers and educators. In the context of an engineering outreach program for elementary students, this study examines the teaching moves of outreach ambassadors, adds to the understanding of their teaching moves, and offers preliminary conjectures about the impact of these moves on students. This study asks: What kinds of discursive teaching moves do outreach ambassadors enact when interacting with elementary student design teams?
\end{abstract}

In the focal outreach program, pairs of university students facilitated engineering design challenges in elementary classrooms for one hour each week throughout the school year. We selectively sampled and analyzed four such sessions in four fourth- and fifth-grade classrooms. We used discourse analysis and a lens of ambitious teaching to classify the teaching moves employed during interactions between ambassadors and small groups of students who were engaged in engineering design challenges. We identified a range of moves, including ambitious, inclusive, and conservative teaching moves, across the four sessions. From class to class, we observed variation in distribution of each category of teaching move and we hypothesize that activity design and outreach ambassador orientations toward teaching influence this variation.

Particularly promising for engineering teaching and learning, we observed ambassadors making bids to elicit student ideas, pressing for evidence-based explanations, and revoicing students' design ideas. These moves are characteristic of ambitious instruction and have the potential to support students to engage in reflective decision-making and to guide students toward productive, more expert engineering design practices. Our analysis suggests that engineering outreach ambassadors notice and respond to students' ideas, thereby engaging in ambitious teaching practices which can be expected to support elementary students in making progress in engineering design. This analysis of outreach ambassadors' discursive interactions with elementary student design teams adds to the growing conversation about ambitious instruction in engineering.

\section{Introduction}

Engineering outreach educators, or engineering outreach ambassadors, have the potential to influence significant numbers of precollege youth; university-led engineering outreach programs reach approximately 600,000 K-12 students each year in the United States [1]. Despite the 
prevalence of these programs, little is known about the ways in which outreach ambassadors influence youths' participation and progress in engineering practices. Understanding the ways in which outreach ambassadors interact with and support youth to learn engineering is critical to furthering the effectiveness of outreach programs and contributes to greater understanding about how to support K-12 engineering education. This study explores the nature of discursive interactions between outreach ambassadors and youth participating in an engineering outreach program and asks: What kinds of discursive teaching moves do outreach ambassadors enact when interacting with elementary student design teams?

\section{Theoretical background}

Typically, engineering ambassadors are placed in classrooms with the intent that they enculturate students into engineering via two functions: modeling and generating enthusiasm for engineering study and careers and guiding engagement in authentic practices of engineering [2]-[5]. In this paper, we use a lens of ambitious instruction to characterize the teaching moves of engineering ambassadors that are likely to support student engagement in engineering practices. We then discuss the implications for better understanding and characterizing how outreach ambassadors support student learning in engineering.

\section{Outreach as a context for studying pedagogical moves}

K-12 engineering outreach programs offer a noteworthy context for studying educators' pedagogical moves. Although engineering ambassadors often (and in the cases presented here) operate in a classroom context, they perform a different role than do classroom teachers and they may hold different pedagogical goals and practice different teaching moves than do other educators [3], [4]. Often, outreach programs are facilitated by undergraduate and graduate students who themselves are developing as engineers and educators. These engineering ambassadors represent a unique teaching population. As disciplinary specialists, they have proximate experience in practices of doing and learning engineering and are well-positioned to enculturate elementary students into these disciplinary practices. At the same time, these ambassadors are novice educators who may not have extensive pedagogical knowledge [4].

While studies have characterized the teaching moves of experienced and novice engineering and science educators, both in and out of school (e.g., [6]-[9]), the nature of engineering ambassadors' teaching moves is less well understood. Given the extensive reach and potential impact of engineering outreach programs, characterizing engineering ambassadors' teaching moves has implications for understanding possibilities and practices in engineering education. This study expands our understanding of educators' teaching moves by focusing on the discursive teaching moves of educators working in a university-led engineering outreach program.

\section{Ambitious instruction}

Ambitious instruction refers to a set of educator practices which support student learning by scaffolding student reasoning about students' own ideas. In ambitious instruction, educators attend to students' thinking and adapt their (educators') pedagogical moves to support students to interrogate and refine their (students') thinking. Attending to student thinking and adapting instruction to support students' sensemaking has also been referred to as discovery teaching (e.g., [10]) or responsive teaching (e.g., [11], [12]). Ambitious instruction and responsive teaching 
have been described in a range of K-12 and post-secondary school settings, including engineering [15], science [11], [16]-[18], mathematics [11], [19], and language classrooms [20]. In engineering, while there is beginning work studying the pedagogical moves of K-12 integrated science and engineering teachers (e.g., [15]), little is known about the pedagogical moves of K12 engineering outreach educators.

We look through a lens of ambitious science teaching (e.g., [17], [18]) to frame our study, because ambitious science teaching practices align with key goals for engineering learning. Ambitious instruction and responsive teaching have been demonstrated to support student learning in science through scaffolding students' participation in sensemaking practices of the discipline [13], [14] Ambitious science instruction orients students toward the "doing of science" versus the "doing of the lesson" [18, p. 759]. Engineering outreach, like informal or outof-school education, seeks for students to experience the "doing of engineering" [22]. Specifically, as we are observing elementary students, we look for evidence that ambassadors are supporting students to do engineering through engaging in reflective decision-making [23]. Ambitious science instruction supports students to generate, build upon, reflect upon, and revise explanations for natural phenomena. Ambitious engineering instruction, we suggest, would support students to generate, build upon, reflect upon, and revise design ideas and solutions. That is, we believe that teaching moves which encourage students' engagement in the practices of science likely correspond with teaching moves which encourage students' engagement in engineering through scaffolding reflective decision-making.

Ambitious science teaching consists of four practices: three classroom discourse practices and one practice of planning and preparation around big ideas in science [18]. As we are interested in classroom discourse, we focus our analysis on the three classroom discourse practices of ambitious science teaching: eliciting students' ideas to adapt instruction, helping students make sense of material activity, and pressing students for evidence-based explanations [14, p. 885]. Teaching moves can involve verbal and somatic moves, including how teachers position themselves physically in relation to students. Within this suite of teacher moves, we forefront ambassadors' talk moves, highlighting the efforts or discursive bids ambassadors make that are likely to support reflective decision-making by students.

\section{Methods}

\section{Study context and participants}

This study took place within a university-led engineering education outreach program in the northeastern United States. In this program, pairs of university students facilitated engineering design challenges in elementary classrooms for one hour each week throughout the school year. We selectively sampled and analyzed six such sessions in six fourth- and fifth-grade classrooms from five socio-economically, ethnically, and linguistically diverse suburban schools. We selected the samples to include a range of students, classrooms, outreach ambassadors, and engineering activities. From each of the six class sessions, we selected one 30-minute video of the outreach ambassadors interacting with one small team of elementary students. We selected two class sessions to develop and refine our coding system, and independently coded four class sessions. Figure 1, below, describes the data set of these four class sessions. All names are pseudonyms which respect the gender of individual participants. To protect confidentiality of participants and also acknowledge the ethnic diversity of participants, the pseudonyms were 
randomly assigned and include a range of culturally-connected names which respect the ethnicities and nationalities of participants.

\begin{tabular}{|l|l|l|l|l|}
\hline Group & $\begin{array}{l}\text { School and } \\
\text { Grade }\end{array}$ & Ambassadors & Students & Engineering Challenge \\
\hline Group 1 & $\begin{array}{l}\text { Cherry, } \\
\text { Grade 4 }\end{array}$ & Dahlia \& Steve & $\begin{array}{l}\text { Diana \& } \\
\text { Henry }\end{array}$ & $\begin{array}{l}\text { Create a music box using LEGO NXT } \\
\text { robotic components }\end{array}$ \\
\hline Group 2 & $\begin{array}{l}\text { Elm, } \\
\text { Grade 4 }\end{array}$ & Fern \& Xander & $\begin{array}{l}\text { Wren \& } \\
\text { Ximena }\end{array}$ & $\begin{array}{l}\text { Improve car safety and build a } \\
\text { model using electronic and craft } \\
\text { materials }\end{array}$ \\
\hline Group 3 & $\begin{array}{l}\text { Willow, } \\
\text { Grade 5 }\end{array}$ & $\begin{array}{l}\text { Tejaswi \& } \\
\text { Nancy }\end{array}$ & $\begin{array}{l}\text { Bella \& } \\
\text { Bonnie }\end{array}$ & $\begin{array}{l}\text { Build a model home to withstand } \\
\text { simulated natural disasters using craft } \\
\text { materials }\end{array}$ \\
\hline Group 4 & $\begin{array}{l}\text { Cherry, } \\
\text { Grade 4 }\end{array}$ & $\begin{array}{l}\text { Olympia } \\
\text { \& Simon }\end{array}$ & $\begin{array}{l}\text { Denise, } \\
\text { Karina, \& } \\
\text { Leslie }\end{array}$ & $\begin{array}{l}\text { Design an air-powered rocket that } \\
\text { reaches a target using craft materials }\end{array}$ \\
\hline
\end{tabular}

Figure 1. Video data set characteristics.

Qualitative coding approach

Educator discourse moves are typically described in reference to dialogic interactions between a teacher and students during whole-class instruction or discussion. However, engineering outreach activities enacted by ambassadors are often not structured for formative or summative wholeclass sensemaking discussions. Within outreach settings, we typically see short whole-class interactions setting up the activity and longer individual or small group interactions during students' hands-on design time. Our data set contained infrequent or brief whole-class discussions and frequent ambassador interactions with small teams of students, yielding opportunities to explore educator discourse in the context of small group interactions.

We focused our analysis on interactions between the ambassadors and one student team in each classroom. After selecting the focal groups, we watched and transcribed the video recordings of each group, and identified the turns of talk in which outreach ambassadors interacted with the focal student groups. We excluded from our analysis any ambassador turns of talk directed to other student groups or the entire class. Our coding approach included three cycles of qualitative coding [24]. In the first and second coding cycles, we collaboratively coded two class sessions and in the third coding cycle we independently coded four class sessions (Figure 2).

\begin{tabular}{|c|c|c|c|}
\hline Coding Cycle & Data Sources & Codes & Coding Process \\
\hline 1 & Group A & $\begin{array}{c}\text { Modified and expanded codes } \\
\text { from Grinath \& Southerland (2019) }\end{array}$ & Collaborative \\
\hline 2 & Group B & $\begin{array}{c}\text { Refined codes to create } \\
\text { final codebook }\end{array}$ & Collaborative \\
\hline 3 & Groups 1-4 & Final codebook & $\begin{array}{c}\text { Independent coding; } \\
\text { reconcile through } \\
\text { discussion }\end{array}$ \\
\hline
\end{tabular}

Figure 2. Analytic approach. 
For our first coding cycle, we applied a modification of Grinath and Southerland's (2019) coding scheme for categorizing teaching moves of university biology teaching assistants to one transcript. This scheme included three categories of teaching moves: ambitious, inclusive, and conservative moves. Drawing on the work of Grinath \& Southerland (2019) and Windschitl et al. (2014), we considered ambitious moves to be educator teaching moves which served to elicit and encourage student reasoning, inclusive moves to be moves which served to give multiple students a voice in the discussion of the design, and conservative moves as moves which served to elicit an anticipated, singular, canonically correct answer. However, we modified Grinath and Southerland's coding scheme to emphasize engineering sensemaking and engineering outreach norms. While science learners aim to develop a common understanding of and explanation for a phenomenon, engineering design learners aim to develop a solution to a problem. Further, in a science classroom, the entire class is working toward one explanation of one phenomenon. In this engineering outreach program, various teams of students work toward a variety of solutions to one problem or a variety of problems. Thus, for our analysis, we modified codes which described scaffolding explaining phenomena to codes which described scaffolding reasoning about design solutions. Specifically, we adapted Grinath and Southerland's ambitious move "probing question" to surface students" ideas about phenomena to become "probing question" to surface students' ideas about their envisioned designs and built artifacts. Similarly, we adapted "press for explanations" of phenomena to become "press for explanations" of student reasoning about a mechanism or a design choice. We added the ambitious code "design checkin" to capture moves through which an ambassador made a bid for students to verbalize their design ideas. Although one might not anticipate that a question such as "How's it going?" would elicit students' design thinking, we noticed that students consistently took up this and similar questions as an invitation to discuss their design ideas and reasoning.

In the second round of coding, we renamed Grinath and Southerland's inclusive move "revoice" a student's verbal contribution to "repeat" a student's verbal contribution and we took revoicing to be an ambitious move in which an ambassador noticed and forefronted a segment of a student's design-related talk or element of a team's design artifact. In our coding scheme, revoicing includes not only paraphrasing and highlighting students' vocalized ideas, but also noticing and forefronting the ideas embodied in students' design artifacts. In our final round of coding, we independently coded four transcripts using the revised coding scheme developed in the prior coding cycle. We compared results and reached $74 \%, 80 \%, 81 \%$, and $87 \%$ inter-rater reliability. We resolved all discrepancies through discussion and came to $100 \%$ consensus. Throughout our analysis, we referred to the video recordings to resolve discrepancies and understand nuances of the ambassador-student interactions. The Appendix includes a list of our codes, descriptions of each code, and examples of educator teaching moves.

\section{Findings}

\section{Overview of findings}

We present the quantitative results of our coding along with rich descriptions of the specific classroom contexts. Our findings show that engineering ambassadors leveraged ambitious, conservative, and inclusive talk moves and that the distribution of those moves varied markedly between classrooms. Our descriptions offer insight into activity and classroom structures that may have impacted the types of teaching moves employed. 
Characterization of outreach ambassadors' teaching moves

Figure 3 shows the distribution of teaching moves for the ambassador pairs in four different classrooms. Ambitious moves ranged from $11 \%$ of ambassador moves up to $48 \%$ of moves, conservative moves ranged from $22 \%$ to $69 \%$, and inclusive moves made up a small portion (from 0 to 6\%) of the interactions in the data set. A small percentage of moves in each classroom (including ambiguous utterances such as "OK") were classified as Other and are not included on the graph for reasons of clarity and space.

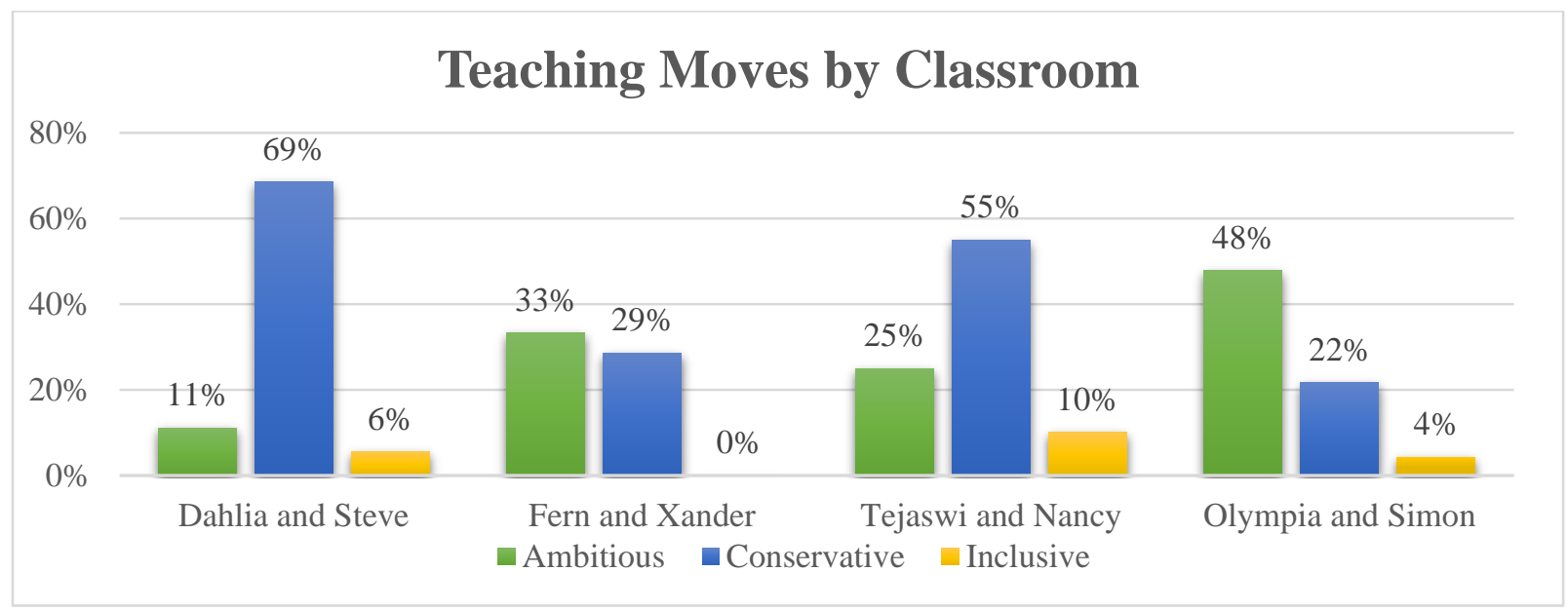

Figure 3. Distribution of teaching moves by ambassador pairs.

The heterogeneity of the results prompted us to look at the specific context of each classroom in greater detail. Figure 4, below, shows that two pairs of ambassadors predominantly employed ambitious teaching moves and two pairs of ambassadors predominantly enacted conservative teaching moves. Considering these moves in the context of student activity led us to conjecture that ambassadors may be supporting distinct pedagogical goals through ambitious and conservative teaching moves. As would be expected, when ambassadors employed ambitious teaching moves, they appeared to be working to support students to generate, reason about, reflect on, or revise design ideas. Often, when ambassadors employed conservative teaching moves, they appeared to be working to help students manipulate or manage materials or attend to design criteria. We present detail from each classroom to illustrate conservative and ambitious teaching moves that may be supporting these two types of goals.

\begin{tabular}{|l|l|l|}
\hline Engineering Challenge & Ambassadors & Dominant Discourse Type \\
\hline Music box using LEGO robotics & Dahlia and Steve & Conservative \\
\hline Car safety using circuits & Fern and Xander & Ambitious \\
\hline $\begin{array}{l}\text { Disaster-proof house using craft } \\
\text { materials }\end{array}$ & Tejaswi and Nancy & Conservative \\
\hline $\begin{array}{l}\text { Air-powered rocket using craft } \\
\text { materials }\end{array}$ & Olympia and Simon & Ambitious \\
\hline
\end{tabular}

Figure 4. Distribution of dominant discourse type by engineering challenge and ambassador pairs. 


\section{Ambitious moves}

Fern and Xander, Car Safety

In this class, each student team picked their own problem to solve, and students Wren and Ximena chose to improve car visibility and safety by making a car with working lights. In this classroom, many of the ambitious moves were design check-in questions or probes to elicit student ideas. Engineering ambassador Fern used probing questions when talking with these students about their ideas and their frustrations, asking "So what is your plan?" when talking to Wren and Ximena about their circuit, and pressing "Why not?" when they told her they were trying one idea and it wasn't working.

\section{Olympia and Simon, Paper Rockets}

Ambassadors Olympia and Simon facilitated an activity in which students built and launched airpowered paper rockets toward a target "planet". This activity was designed for frequent iteration by the students, who could build and test quickly with simple materials. Simon used revoicing and probing questions to talk students Denise, Karina, and Leslie through their test results and their ideas about what to do for their next design. Similarly, Olympia revoiced the students' interpretation of their test results and pressed them to reason about the test results. These teaching moves were followed by students discussing their plans to make the rocket more accurate. In the examples above, Fern, Olympia, and Simon utilized ambitious teaching moves when they identified opportunities for students to reason about their design decisions.

\section{Conservative moves}

\section{Dahlia and Steve, Music Box}

Ambassadors Dahlia and Steve presented students with a challenge to make a moving music box out of LEGO robotics kits using gears and a motor. When talking with students Diana and Henry, engineering ambassador Steve used conservative moves to clarify the task and help the students advance the function of their design, talking to the students about what music boxes were and how to make the gears spin. Henry, one of the students, asked Steve, "Like could it (a motor) like attach to it (the gear train) and make it like spin?" Steve replied, saying "Yeah you could make it spin if you wanted to. But right now, if you opened your music box and it's just this (gear train), this (gear train) won't spin by itself, right? You'd have to get someone to move it (a gear) around. So I'd start thinking about different ways you can attach this (motor)." This conservative minilecture offered both content and a starting suggestion for the students.

\section{Tejaswi and Nancy, Disaster-Proof House}

In this engineering activity, students designed and built miniature flood- and earthquake-proof houses from craft materials while remaining within a budget set by the engineering ambassadors. In this classroom, Tejaswi's conservative moves appeared to focus on helping Bella and Bonnie meet the design criteria. Tejaswi noticed Bella and Bonnie were using a large portion of their supply budget to purchase tape and asked, "Let's just try to think, though, like, when we put a piece of duct tape here (on the model house) does every part need to be connected or can we do with just a piece here and piece here?" She used a conservative minilecture to offer a suggestion to help these students use materials efficiently and stay within budget parameters. Tejaswi, here, and Steve, above, used conservative moves in situations when they identified that students' material choices might have budgetary or mechanistic consequences that would impede their ability to fully address the functional design requirements. 


\section{Limitations}

We selected these particular outreach sessions to ensure we were viewing a variety of ambassadors, students, and engineering activities. However, our selection of videos was constrained by the limits of video recording in outreach classrooms. In classrooms, students occasionally walked out of view of the video cameras or out of range of the audio recorders to get additional materials or to test solutions. Often, multiple teams gathered near each other to test solutions. In these situations, several students could be talking simultaneously, making it difficult to identify which students were interacting with an engineering ambassador while testing their designs. To obtain interpretable 30-minute segments of student activity and interactions with ambassadors, we selected outreach sessions which centered on planning, building, and responding to testing outcomes in small groups. The data presented here did not include ambassador interactions with student teams who were actively testing or communicating solutions while at testing stations. It is possible that engineering ambassadors would utilize a different range of teaching moves when interacting with student teams that are testing or sharing out solutions.

We did not observe ambassadors employing two of the three inclusive teaching moves identified in Grinath and Southerland's (2019) work; we did not observe ambassadors acknowledging students' contributions or distributing participation in this data set. As we limited our data set to ambassadors' interactions with small groups and we excluded whole-class instruction, we would not have observed any acknowledgments intended to focus the entire class's attention on one student's thinking. However, we can envision that ambassadors might acknowledge the value of a student's contribution either to their team or to the whole class. For example, it is possible that an ambassador might highlight a student's reasoning about test results; this form of acknowledging students' contributions might be present in a data set focused on discourse during testing. Additionally, although we did not observe ambassadors attempting to distribute participation, we can imagine engineering ambassadors might encourage students to talk about the ideas of everyone on the team and to figure out a way to include everyone's ideas. It is possible that we selected groups that were participating equitably, and ambassadors did not see a need to distribute participation. Alternatively, it is possible that ambassadors chose to focus on something other than distributing participation in the sessions we analyzed.

\section{Discussion}

Our work is formative in terms of characterizing engineering ambassador discourse and identifying discursive patterns that are likely to support student progress in engineering design. Within science education, ambitious teaching moves generally support students' science learning [17], [18]. However, while it is reasonable to believe that ambitious teaching moves are similarly likely to support students' engineering learning, within engineering outreach, it is not clear that ambitious moves are the only teaching moves which support students' productive participation in engineering design. Our data suggests that at times, conservative moves could be envisioned to support students to re-engage with design decisions, reflect on design solutions, or remove a technical barrier to more substantive design work. For example, we observed interactions in which providing information (a conservative teaching move) scaffolded students to continue their work and advance their design. Figure 5, below, shows engineering ambassador Fern 
identifying an issue with Ximena and Wren's circuit design and providing information on how to fix it.

\begin{tabular}{|c|c|c|c|}
\hline Line & Speaker & Transcript & Teaching Move \\
\hline 1 & Fern & What's going on, how can I help? & Ambitious: Design check-in \\
\hline 2 & Ximena & $\begin{array}{l}\text { We can't make this (circuit). It's, like, } \\
\text { impossible. }\end{array}$ & \\
\hline 3 & Fern & $\begin{array}{l}\text { All right, I can tell you the problem right } \\
\text { now. What's going on is right now, the } \\
\text { electrons are going out of this terminal (of } \\
\text { the cell), this end, through the playdough and } \\
\text { right back. So when you connect, like, an } \\
\text { LED to it, it's doing what's called short } \\
\text { circuiting. So it's going right from here to } \\
\text { here (terminals on the battery), it's not } \\
\text { taking any detours to go to your LEDs. So, if } \\
\text { you split it up and you did something like } \\
\text { this- }\end{array}$ & Conservative: Minilecture \\
\hline 4 & Wren & $\begin{array}{l}\text { And then we attach the wires to the } \\
\text { playdough? }\end{array}$ & \\
\hline 5 & Fern & Yep, that will probably help you a lot, OK? & Conservative: Minilecture \\
\hline
\end{tabular}

Figure 5: Engineering ambassador Fern with students Ximena and Wren.

Within a design context, Fern's teaching moves are productive for advancing the students to a functional design. To help students get past a technical barrier that was preventing them from continuing to build their design, Fern leveraged conservative moves by explaining how the battery and LED were short circuiting. More work is needed to understand what balance of ambitious and conservative moves are productive for outreach settings and in which specific interactions conservative moves might be necessary.

Our findings show different distributions of ambitious and conservative teaching moves used by engineering ambassadors. The fact that engineering ambassadors used ambitious teaching moves at all without prior directed training is significant given the attention to developing these moves in pre- and in-service teachers [13]. We also found that the ambitious moves being taken up by engineering ambassadors were not only focused on students' talk, but also their builds. Future work could explore the ways in and extent to which engineering educators attend to the physical manifestations of students' design thinking. Ambassadors made discursive bids to help students interpret their testing, think through design constraints, and give voice to what they were building - all instructional moves that support students engaging in engineering practices in informed ways.

This work suggests that ambitious teaching practices may be a useful framework for engineering outreach to support goals of guiding engagement in authentic practices of engineering [2]-[5]. Moreover, it points toward a potential alignment between ambitious science teaching goals of supporting students to "do science" with engineering outreach goals of helping students "do 
engineering" [21]. We see this in a sample from ambassador Simon's classroom (Figure 6). In this exchange, Simon converses with students as they return from testing a paper rocket.

\begin{tabular}{|c|c|c|c|}
\hline Line & Speaker & Transcript & Teaching Move \\
\hline 1 & Simon & How'd your other designs go? & Ambitious: Probe \\
\hline 2 & Leslie & Good. & \\
\hline 3 & Karina & $\begin{array}{l}\text { Well, we just tested the super } \\
\text { mushroom ("super mushroom" is the } \\
\text { name of one of this team's design } \\
\text { iterations). }\end{array}$ & \\
\hline 4 & Simon & How'd the super mushroom do? & Ambitious: Probe \\
\hline 5 & Leslie & The super mushroom went really good. & \\
\hline 6 & Simon & Oh, wow. & Other \\
\hline 7 & Leslie & $\begin{array}{l}\text { Our third time was a little bit off course. } \\
\text { Fourth was the best. }\end{array}$ & \\
\hline 8 & Karina & Our fourth was the best. & \\
\hline 9 & Simon & $\begin{array}{l}\text { So the third one got like the right distance } \\
\text { right? You made it like- (He points to the } \\
\text { team's data sheet) }\end{array}$ & Ambitious: Revoice \\
\hline 10 & Leslie & Yeah. & \\
\hline 11 & Simon & $\begin{array}{l}\text { If it was straight it would have gone in } \\
\text { the hula hoop (the target)? }\end{array}$ & Ambitious: Revoice \\
\hline 12 & Leslie & Yeah. & \\
\hline 13 & Karina & But the fourth - the fourth was closer. & \\
\hline 14 & Simon & The fourth was like right there? & Ambitious: Revoice \\
\hline 15 & Leslie & Yeah. & \\
\hline 16 & Simon & Awesome. & Other \\
\hline 17 & Leslie & $\begin{array}{l}\text { Our idea is - so if we start off here, it } \\
\text { goes a little bit off course. So we started } \\
\text { about here and it went straight ahead to } \\
\text { where we need it to go. }\end{array}$ & \\
\hline 18 & Simon & Cool. & Other \\
\hline 19 & Karina & $\begin{array}{l}\text { I cut out an original shape and I'm } \\
\text { folding it in half. And then tracing the } \\
\text { shape so it will be the exact same size. }\end{array}$ & \\
\hline 20 & Simon & Awesome & Other \\
\hline 21 & Leslie & $\begin{array}{l}\text { 'Cause we need wings for it so that it will } \\
\text { stay up. }\end{array}$ & \\
\hline 22 & Simon & $\begin{array}{l}\text { Yeah. So what did you change between } \\
\text { the mushroom and the super mushroom? }\end{array}$ & Ambitious: Probe \\
\hline
\end{tabular}

Figure 6: Engineering ambassador Simon and students Denise, Karina, and Leslie. 
Simon uses a series of ambitious moves during this conversation, predominantly using probing and revoicing moves. He looks on with the group at the data sheet that holds their testing results and revoices what they are telling and showing him (lines 9, 11, and 14). The conversation ends when Simon sees that all three girls are planning and discussing their next steps for their rocket, using a probing ambitious move to ask, "What did you change between the mushroom (one iteration) and the super mushroom (another iteration)?" (line 22). In this series of moves, the engineering ambassador directs attention to details from testing, calls back to previous tests, and makes a bid for students to compare designs - all of which is likely to support the students to engage in reflective decision-making, or making design decisions based on evidence from artifacts [23].

We emphasize that we are only making claims about ambitious instruction in outreach settings. We cannot compare to in-service teachers or discuss the needs of classrooms that might need to incorporate science and engineering closely together during instruction. In an outreach setting, where engineering can stand at the forefront of an activity, future research should explore how ambitious instruction is adapted for engineering outreach settings and which attributes of lessons contribute to ambassadors utilizing ambitious moves and in which situations ambassadors' moves are most impactful for advancing students' engineering practice.

\section{Future Directions}

We view this study as a step towards understanding how ambitious instruction interacts with engineering learning goals. Although our characterizations of these outreach ambassadors' teaching moves are by no means absolute, the process of modifying existing characterizations of teaching moves to fit engineering offers important preliminary insights into how ambitious teaching moves might support engineering learning and the work that still needs to be done. To more fully understand ambitious instruction in engineering education, future work should consider ways in which existing frameworks of ambitious instruction might correspond with and differ from ambitious instruction in engineering education contexts. Students doing engineering work in elementary classrooms are often engaged with physical artifacts and builds. Engineering educators may call attention to these artifacts or ask about design choices they see in an artifact to help students interpret phenomena and test results. We considered outreach ambassadors' attention to students' artifacts to be evidence of ambassadors' attention to students' ideas. Future work could investigate interactions between educators' attention to students' artifacts and educators' support of students' reasoning. Additionally, ambitious instruction research is often grounded in whole-class interactions. The small group work of engineering, in which each group member is invested in the physical artifact but may have different ideas about design or test results, presents a different dynamic for ambassadors to notice and address than has been addressed in the ambitious science teaching literature.

Our data shows differences across classrooms in the distribution of moves used by engineering ambassadors. Future research could explore if the types and frequency of engineering ambassadors' teaching moves vary with differences in the focus of design activities, phases in the design process, group size, or ambassadors' individual pedagogical goals, stances, or experience. Future research could explore expanding and refining descriptions of engineering ambassadors' teaching moves, building toward a robust characterization of ambitious instruction in engineering outreach education. Finally, key to developing a characterization of ambitious 
instruction within engineering outreach will be exploring the ways in which students take up and respond to moves made by engineering ambassadors. As we expect ambitious instruction to support students to sensemake in science, so too should we anticipate ambitious instruction to support students to engage in reflective decision making in engineering. Understanding the patterns of ambassador talk moves and subsequent student actions will be important to understanding when students are engaging in meaningful work and reflection, and in what ways ambassadors' moves are supporting students to engage in reflective design.

\section{Acknowledgements}

We thank the students for their participation in this study and their teachers and families for facilitating the students' participation. We thank the research team members who made this study possible. This material is based upon work supported by the National Science Foundation under Grants Nos. DRL-1657509 and DRL-1657519. Any opinions, findings, and conclusions or recommendations expressed in this material are those of the authors and do not necessarily reflect the views of the National Science Foundation.

\section{References}

[1] E. Iversen, "Engineering outreach on campus," Washington, DC, USA, 2015.

[2] M. U. Bers and M. Portsmore, "Teaching partnerships: Early childhood and engineering students teaching math and science through robotics," J. Sci. Educ. Technol., vol. 14, no. 1, pp. 59-73, 2005.

[3] K. E. Bledsoe, R. Shieh, Y.-S. Park, and E. Gummer, "Role perceptions and role dynamics between graduate scientists and K-12 teachers in a school-university outreach project: Understudied constructs," J. High. Educ. Outreach Engagem., vol. 9, no. 2, pp. 107-122, 2004.

[4] C. Gartland, "Student ambassadors: 'Role-models', learning practices and identities," $\mathrm{Br}$. J. Sociol. Educ., 2015.

[5] M. Portsmore, C. Rogers, and M. Pickering, "STOMP: Student Teacher Outreach Mentorship Program.” Proc. 2003 Annu. Conf. American Soc. Engineering Education, Nashville, TN, USA. https://peer.asee.org/12664.

[6] J. DeWitt and J. Hohenstein, "School trips and classroom lessons: An investigation into teacher-student talk in two settings," J. Res. Sci. Teach., vol. 47, no. 4, pp. 454-473, 2010.

[7] C. E. Hmelo-Silver and H. S. Barrows, "Goals and strategies of a problem-based learning facilitator," Interdiscip. J. Probl. Learn., vol. 1, no. 1, pp. 5-22, 2006.

[8] S. Michaels, C. O’Connor, and L. B. Resnick, "Deliberative discourse idealized and realized: Accountable talk in the classroom and in civic life," Stud. Philos. Educ., vol. 27, no. 4, pp. 283-297, 2008.

[9] J. Zhai and J. Dillon, "Communicating science to students: Investigating professional botanic garden educators' talk during guided school visits," J. Res. Sci. Teach., vol. 51, no. 4, pp. 407-429, 2014.

[10] D. Hammer, "Discovery learning and discovery teaching," Cogn. Instr., vol. 15, no. 4, pp. 485-529, 1997.

[11] A. D. Robertson, R. E. Scherr, and D. Hammer, Eds., Responsive Teaching in Science and Mathematics. New York: Routledge, 2016.

[12] J. Watkins et al., "Data-based conjectures for supporting responsive teaching in engineering design with elementary teachers," Sci. Educ., vol. 102, no. 3, pp. 548-570, 2018. 
[13] D. Stroupe, "Examining classroom science practice communities: How teachers and students negotiate epistemic agency and learn Science-as-Practice," Sci. Educ., vol. 98, no. 3, pp. 487-516, 2014.

[14] D. Stroupe, "Ambitious teachers' design and use of classrooms as a place of science," Sci. Educ., vol. 101, no. 3, pp. 458-485, 2017.

[15] B. M. Capobianco, J. DeLisi, and J. Radloff, "Characterizing elementary teachers' enactment of high-leverage practices through engineering design-based science instruction," Sci. Educ., vol. 102, no. 2, pp. 342-376, 2018.

[16] A. S. Grinath and S. A. Southerland, "Applying the ambitious science teaching framework in undergraduate biology: Responsive talk moves that support explanatory rigor," Sci. Educ., vol. 103, no. 1, pp. 92-122, 2019.

[17] M. Windschitl, J. Thompson, M. Braaten, and D. Stroupe, "Proposing a core set of instructional practices and tools for teachers of science," Sci. Educ., vol. 96, no. 5, pp. 878-903, 2012.

[18] M. Windschitl, J. Thompson, and M. Braaten, Ambitious Science Teaching. Cambridge: Harvard University Press, 2018.

[19] M. K. Stein, R. A. Engle, M. S. Smith, and E. K. Hughes, "Orchestrating productive mathematical discussions: Five practices for helping teachers move beyond show and tell," Math. Think. Learn., vol. 10, no. 4, pp. 313-340, 2008.

[20] M. Lampert, T. Boerst, and F. Graziani, "Organizational resources in the service of school-wide ambitious teaching practice," Teach. Coll. Rec., vol. 113, no. 7, pp. 13611400, 2011.

[21] M. P. Jimenez-Aleixandre, A. B. Rodriguez, and R. A. Duschl, “'Doing the lesson' or 'doing science': Argument in high school genetics," Sci. Educ., vol. 84, no. 6, pp. $757-$ $792,2000$.

[22] A. J. Friedman. (Ed.), "Framework for evaluating impacts of informal science education projects," 2008 Accessed Mar. 162020 [Online]. Available: http://insciorg/resources/Eval_Framework.pdf.

[23] K. B. Wendell, C. G. Wright, and P. Paugh, "Reflective decision-making in elementary students' engineering design," J. Eng. Educ., 2017.

[24] M. B. Miles, A. M. Huberman, and J. Saldaña, Qualitative Data Analysis: A Methods Sourcebook. Thousand Oaks: Sage, 2013. 


\section{Appendix}

\section{Codebook}

\begin{tabular}{|c|c|c|}
\hline $\begin{array}{l}\text { Code Category } \\
\text { Code }\end{array}$ & Definition & Examples \\
\hline \multicolumn{3}{|l|}{ Ambitious } \\
\hline Design check-in & $\begin{array}{l}\text { An open-ended } \\
\text { question that, while it } \\
\text { does not specifically } \\
\text { reference a group's } \\
\text { design, serves to } \\
\text { surface students' } \\
\text { design ideas. }\end{array}$ & $\begin{array}{l}\text { How's it going? } \\
\text { How's it coming along? } \\
\text { What's going on? }\end{array}$ \\
\hline Probing question & $\begin{array}{l}\text { An open-ended } \\
\text { question that focuses } \\
\text { on a student's design } \\
\text { ideas or thinking (and } \\
\text { serves to surface } \\
\text { student ideas about } \\
\text { their design). }\end{array}$ & $\begin{array}{l}\text { How's the music box coming along? } \\
\text { How did the Super Mushroom [a } \\
\text { solution iteration] do [in the test]? } \\
\text { What's your next idea to make it better? }\end{array}$ \\
\hline Press for explanation & $\begin{array}{l}\text { Press for student } \\
\text { reasoning about a } \\
\text { mechanism or a } \\
\text { design choice. }\end{array}$ & $\begin{array}{l}\text { Why do you think that [test result] was } \\
\text { happening? } \\
\text { Student: We tried, but it doesn't work. } \\
\text { Ambassador: Why not? }\end{array}$ \\
\hline Revoice or reflect & \begin{tabular}{|l|} 
Paraphrasing or \\
highlighting a \\
selection of a student's \\
design- \\
related comment, \\
or voicing what the \\
ambassador notices \\
the student is doing \\
with their design.
\end{tabular} & $\begin{array}{l}\text { Student: Our third time was a little bit off } \\
\text { course. Fourth was the best. } \\
\text { Ambassador: So the third one got the right } \\
\text { distance, right? If it was straight it would } \\
\text { have gone [to the target]? } \\
\text { [Looking at what students have built] So } \\
\text { you have all these [connected gears] and } \\
\text { these all kind of spin together, right? }\end{array}$ \\
\hline \multicolumn{3}{|l|}{ Conservative } \\
\hline Display question & $\begin{array}{l}\text { Request for simple } \\
\text { facts, procedures, or } \\
\text { identification of } \\
\text { students' status in the } \\
\text { activity; prompts for a } \\
\text { report or a single } \\
\text { correct answer. }\end{array}$ & $\begin{array}{l}\text { Have you seen a music box before? What } \\
\text { happens when you open it up? } \\
\text { What do think you should do with the } \\
\text { middle of [the gears]? }\end{array}$ \\
\hline
\end{tabular}




\begin{tabular}{|c|c|c|}
\hline $\begin{array}{l}\text { Evaluate product, } \\
\text { process, or reasoning }\end{array}$ & $\begin{array}{l}\text { Categorize student's } \\
\text { response, product, or } \\
\text { process as correct or } \\
\text { incorrect. }\end{array}$ & $\begin{array}{l}\text { That's a good idea. I support that. } \\
\text { But right now I think that's really cool, } \\
\text { especially the way all of the different ones } \\
\text { [gears] spin. }\end{array}$ \\
\hline $\begin{array}{l}\text { Minilecture or } \\
\text { suggestion }\end{array}$ & $\begin{array}{l}\text { Respond to student } \\
\text { contribution by } \\
\text { delivering content in } \\
\text { the form of a design- } \\
\text { related suggestion, } \\
\text { content about the } \\
\text { activity, or } \\
\text { disciplinary norms. } \\
\end{array}$ & $\begin{array}{l}\text { Tin foil's really good for waterproofing. } \\
\text { What's going on is right now, the electrons } \\
\text { are going out of this terminal, this end [of } \\
\text { the cell], through the playdough and right } \\
\text { back. So when you connect an LED to it, } \\
\text { it's doing what's called short circuiting. }\end{array}$ \\
\hline Process management & $\begin{array}{l}\text { Reminder students } \\
\text { about the activity } \\
\text { instructions, materials, } \\
\text { or time. }\end{array}$ & $\begin{array}{l}\text { If you have leftover money this week, you } \\
\text { can use it next week. } \\
\text { Do you guys have your data sheet? }\end{array}$ \\
\hline \multicolumn{3}{|l|}{ Inclusive } \\
\hline $\begin{array}{l}\text { Distribute } \\
\text { participation }\end{array}$ & $\begin{array}{l}\text { Provide opportunity } \\
\text { for additional students } \\
\text { to contribute, respond, } \\
\text { or build. }\end{array}$ & $\begin{array}{l}\text { Not seen in our data to date. } \\
\text { Envisioned example: Can you work on the } \\
\text { rocket wings if your partner works on the } \\
\text { nose cone? }\end{array}$ \\
\hline $\begin{array}{l}\text { Acknowledge } \\
\text { contribution }\end{array}$ & $\begin{array}{l}\text { Indicate student's } \\
\text { contribution is } \\
\text { valuable without } \\
\text { indicating } \\
\text { correctness. }\end{array}$ & $\begin{array}{l}\text { Not seen in our data to date. } \\
\text { Envisioned example: I'm hearing what } \\
\text { you're saying. }\end{array}$ \\
\hline Repeat & \begin{tabular}{|l|} 
Repeat student's \\
contribution to ask for \\
clarification or \\
recognize that a \\
student has spoken
\end{tabular} & $\begin{array}{l}\text { Student: Would this work? } \\
\text { Ambassador: Would that work? } \\
\text { Student: And if you put 'em on something, } \\
\text { from what [my partner] said, they go up. } \\
\text { Ambassador: They go up. }\end{array}$ \\
\hline \multicolumn{3}{|l|}{ Other } \\
\hline Other & $\begin{array}{l}\text { Filler words (e.g., } \\
\text { "OK") and unspecific } \\
\text { feedback (e.g., } \\
\text { "awesome") }\end{array}$ & $\begin{array}{l}\text { Awesome! } \\
\text { Interesting! } \\
\text { You guys got it. }\end{array}$ \\
\hline
\end{tabular}

